\title{
Critical role of cytosolic phospholipase A2 $\alpha$ in bronchial mucus hypersecretion in
} CFTR-deficient mice

\author{
F. Dif*,\#,\#\#, Y-Z. Wü*\#,\#\#, P-R. Burgel ${ }^{\star}$, M. Ollero+, D. Leduc*,\# , J. Aarbiou ${ }^{\S}$, F. Borot $^{+}$, \\ I. Garcia-Verdugo**\#, C. Martin ${ }^{\star}$, M. Chignard*,*, D. Israel-Biet ${ }^{\dagger}$, Y. Kita**, \\ B.J. Scholte ${ }^{\S}$ and L. Touqui*,\#
}

ABSTRACT: Cystic fibrosis (CF) is due to mutations in the CF transmembrane conductance regulator gene CFTR. CF is characterised by mucus dehydration, chronic bacterial infection and inflammation, and increased levels of cytosolic phospholipase A2 $\alpha$ (CPLA2 $\alpha$ ) products in airways.

We aimed to examine the role of CPLA2 $\alpha$ in the modulation of mucus production and inflammation in CFTR-deficient mice and epithelial cells. Mucus production was assessed using histological analyses, immuno-histochemistry and MUC5AC ELISA. CPLA2 $\alpha$ activation was measured using an enzymatic assay and lung inflammation determined by histological analyses and polymorphonuclear neutrophil counts in bronchoalveolar lavages.

In lungs from $\mathrm{Cftr}^{-1-}$ mice, lipopolysaccharide induced mucus overproduction and MUC5AC expression associated with an increased CPLA2 $\alpha$ activity. Mucus overproduction was mimicked by instillation of the CPLA2 $\alpha$ product arachidonic acid, and abolished by either a cPLA2 $\alpha$ null mutation or pharmacological inhibition. An increased cPLA2 $\alpha$ activity was observed in bronchial explants from CF patients. CFTR silencing induced CPLA2 $\alpha$ activation and MUC5AC expression in bronchial human epithelial cells. This expression was enhanced by arachidonic acid and reduced by CPLA2 $\alpha$ inhibition. However, inhibition of CFTR chloride transport function had no effect on MUC5AC expression.

Reduction of CFTR expression increased CPLA2 $\alpha$ activity. This led to an enhanced mucus production in airway epithelia independent of CFTR chloride transport function. CPLA2 $\alpha$ represents a suitable new target for therapeutic intervention in CF.

KEYWORDS: Arachidonic acid, cystic fibrosis, lipopolysaccharide, MUC5AC, mucus, phospholipase A2

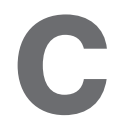
ystic fibrosis (CF) is a common recessively inherited disorder in the Caucasian population due to mutations in the $\mathrm{CF}$ transmembrane conductance regulator gene CFTR. The most common mutation results in the absence of a phenylalanine residue at aminoacid position 508 (F508del) [1]. Mutations of CFTR cause dysfunction of chloride and sodium channels leading to airway mucus abnormality, a critical pathophysiological feature of CF [2]. This leads to airway obstruction, chronic bacterial infection, in particular by Pseudomonas aeruginosa, and inflammation that results in a dramatic respiratory insufficiency, the major cause of mortality in CF patients [3-5].
Normally, the epithelium of conducting airways is covered with a thin layer of mucus that plays important roles in airway defence against inhaled pathogens by facilitating their clearance via mucociliary clearance to the upper airways [68]. Mucins are large glycoproteins secreted in the airway lumen by epithelial and submucosal gland cells. Mucins MUC5AC and MUC5B have been identified as important components of airway mucus in normal subjects [9]. In patients with $\mathrm{CF}$, airway disease is characterised by progressive airway obstruction by mucous secretions [10]. Studies of mucins in CF airways excised at the time of transplantation have shown that: 1) MUC5AC mRNA expression is increased
AFFILIATIONS

*Unité de Défense Innée et Inflammation,

\#Unité Inserm U. 874, Institut Pasteur,

•Université René Descartes, UPRES

EA 2511 Hôpital Cochin AP-HP

${ }^{+}$Inserm U845, Université Paris

Descartes,

${ }^{\text {f}}$ Service de Pneumologie, Hôpital

Européen Georges Pompidou, Paris, France.

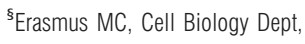
Rotterdam, The Netherlands.

${ }^{* *}$ Dept of Biochemistry and Molecular Biology, Faculty of Medicine, The University of Tokyo, Tokyo, Japan.

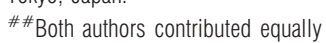
to this work.

\section{CORRESPONDENCE}

L. Touqui

Unité de Défense Innée et

Inflammation

Unité Inserm U. 874

Institut Pasteur

25 rue du Dr Roux

75015 Paris

France

E-mail: touqui@pasteur.fr

Received:

Nov 182009

Accepted after revision:

March 312010

First published online:

April 222010 
in $\mathrm{CF}$ epithelium compared to the epithelium of control subjects [11], 2) immunostaining for MUC5AC protein is increased in CF epithelium compared with control subjects $[12,13], 3)$ MUC5AC protein is present in the airway lumen of CF subjects, contributing to airway plugging [12, 13] and 4) MUC5B is also increased in CF airway epithelium and lumen $[12,13]$. Altogether, these data suggest that overproduction and secretion of MUC5AC and MUC5B mucins may occur in $\mathrm{CF}$ airways and contribute to their progressive plugging. A recent paper by GARCIA et al. [14] showed that CFTR activity is required for normal hydration and secretion of intestinal mucin in a mouse model of CF. It is inferred that a similar mechanism may play a role in CF airways [14]. This does not exclude mucus hypersecretion and goblet cell hyperplasia as contributing factors.

Many studies have examined the mechanisms involved in the induction of pulmonary mucus hypersecretion and mucin expression in various animal models of asthma $[15,16]$ and chronic obstructive pulmonary disease [17]. Although CFTR mutations have been shown to induce mucus dehydration and accumulation, the impact of these mutations on mucin expression is still unclear. This expression can be a direct consequence of CFTR alteration or secondary to the exacerbated inflammation that CFTR alteration induces in the lung. Although increased production of various arachidonic acid metabolites, including leukotriene $\mathrm{B}_{4}$, has been reported in airways of CF patients [18] the levels of cysteinyl leukotrienes, known to induce mucus production [16, 19], remained unknown. We have recently shown that a key enzyme involved in the release of arachidonic acid, cytosolic phospholipase (cPLA) A2 $\alpha$, forms complexes with CFTR, and therefore may play a critical role in the pathogenesis of CF [20]. CPLA2 $\alpha$ hydrolyses membrane phospholipids at the sn-2 position leading to a selective release of arachidonic acid [21, 22]. The latter is further converted by cyclooxygenase and lipoxygenase into prostaglandins (PG) and leukotrienes (LT), respectively $[23,24]$, among other mediators. The implication of cPLA2 $\alpha$ in the development of lung inflammation has been extensively examined in various animal models of lung inflammatory diseases [25-27] but its involvement in CF, and in particular, in airway mucus secretion has not been addressed. The present study aimed to investigate the role of cPLA $2 \alpha$ in lipopolysaccharide (LPS)-induced lung mucus production in a mouse model of CF (Cftr-/- mice) and CFTR-deficient human bronchial epithelial cells.

\section{MATERIALS AND METHODS}

\section{Mice}

$\mathrm{Cftr}^{-/-}$(C57BL/6J Cftr ${ }^{\text {m1UNC }}$ ), established by gene targeting [28], were obtained from the "Centre de Distribution, de Typage et d'Archivage Animal" (Orleans, France). After weaning, a commercial osmotic laxative (Movicol ${ }_{\circledR}$; Norgine, Middlesex, UK) was provided in the drinking water to increase the survival of $\mathrm{Cftr}^{-/-}$mice. C57BL/6J/cPLA2 $\alpha$-null mice were established as previously reported [27] and fed a standard laboratory diet and water. Experiments were performed on 8 12-week-old mice, using at least six mice in each group. Mice were cared for in accordance with Pasteur Institute, Paris, France guidelines in compliance with European animal welfare regulations.

\section{LPS and arachidonyl trifluoromethyl ketone instillations}

Mice were anesthetised with xylazine $2 \%\left(8 \mathrm{mg} \cdot \mathrm{kg}^{-1}\right)$ (Rompum, Bayer Healthcare, Puteaux France) and Ketamine 1000 $\left(40 \mathrm{mg} \cdot \mathrm{kg}^{-1}\right)$ (Imalgène1000 Merial, Lyon, France) and treated with the CPLA2 $\alpha$ inhibitor, arachidonyl trifluoromethyl ketone (ATK) (Sigma, St. Louis, MO, USA) as previously described [29]. Briefly, mice received intraperitoneal instillation of ATK $\left(20 \mathrm{mg} \cdot \mathrm{kg}^{-1}\right)$ in $20 \%$ ethanol solution, or the same volume of this solution. After $1 \mathrm{~h}$, mice received intratracheal instillation of $P$. aeruginosa LPS (330 $\mu \mathrm{g} \cdot \mathrm{kg}^{-1}$ in $20 \mu \mathrm{L}$ PBS) (serotype 10; Sigma). Mice received a second intraperitoneal instillation of ATK $\left(20 \mathrm{mg} \cdot \mathrm{kg}^{-1}\right) 24 \mathrm{~h}$ later. Bronchoalveolar lavages (BALs) were performed with PBS, 24 h or 4 days after LPS instillation. PBS was introduced slowly over $1 \mathrm{~min}$ to minimise trauma and hence red blood cell contamination. The extent of inflammation was assessed by measuring polymorphonuclear neutrophil (PMN) counts performed as previously described [30].

\section{Tissue fixation and histological staining of tissue sections}

Lungs were flushed to remove blood, immersed in $4 \%$ formaldehyde for $48 \mathrm{~h}$ at $4^{\circ} \mathrm{C}$ and processed for paraffin inclusion. Analyses of cells present in the epithelia lining the small and the large intrapulmonary bronchi were performed as previously described [31]. Longitudinal and transversal sections of the major intrapulmonary bronchi of $5-\mu \mathrm{m}$ thickness were prepared and stained with Haematoxylin/eosin (H\&E), periodic acid-Schiff (PAS) or Alcian blue (AB; $\mathrm{pH}$ 2.4). Sections (five sections per mouse) were made to visualise large and small airways in all experimental groups. Mucus scores were established in a doubleblinded fashion by two independent observers under the supervision of a pathologist counting AB-positive cells, in 30 fields per mouse on $400 \times$ magnification, as previously reported $[31,32]$. The score analyses are shown (table 1 in the online supplementary material) and their statistical analyses performed as indicated in the section "statistical analyses".

\section{Immunohistochemistry}

MUC5AC immunohistochemisty

Paraffin sections $(5 \mu \mathrm{m})$ of mouse lungs were stained with a specific monoclonal antibody directed against MUC5AC (clone 45 M1; Neomarkers, Fermont, CA, USA). After $2 \mathrm{~h}$ at room temperature, sections were washed with PBS containing $2 \%$ bovine serum albumin (BSA) for $30 \mathrm{~min}$ and incubated with an immunoglobulin (Ig) G conjugated horseradish peroxidase anti-mouse (Dako Cytomation Envision System, Carpinteria, CA, USA). Sections were then washed and stained with amino ethyl carbazol (Sigma).

\section{CPLA2 $\alpha$ immunohistochemistry}

$5-\mu \mathrm{m}$ sections of human bronchial explants were incubated with a specific rabbit polyclonal antibody raised against phospho-cPLA2 $\alpha$ (1:50 dilution; Cell signalling, Boston, MA, USA) at room temperature for $1 \mathrm{~h}$. After washing with PBS, sections were incubated with a biotinylated horse anti-rabbit antibody (1:200 dilution; Vector laboratories, Burlingame, CA, USA). The results were revealed with avidin-biotin-peroxidase complex method (Elite ABC kit; Vector laboratories).

\section{Epithelial cell incubations}

NCI-H292 cells were grown in RPMI-1640 medium as previously described [33], pre-incubated with cPLA2 $\alpha$ inhibitors 
methyl arachidonyl fluorophosphonate (MAFP) or Pyrrolidine-1 for $1 \mathrm{~h}$ before stimulation with LPS, transformin growth factor (TGF)- $\alpha$ or phorbol myristate acetate (PMA). The concentrations of these compounds were adopted based on previous publications. In other studies, cells were transfected with CFTR siRNA (Sigma) and corresponding siRNA control using TransIT-siQUEST $_{\circledR}$ transfection reagent according to the manufacturer's instructions (Mirus, Madison, WI, USA). The cells were then incubated for $1 \mathrm{~h}$ with MAFP followed by $24 \mathrm{~h}$ stimulation with PMA.

\section{Measurements of cPLA2 $\alpha$ activity and free arachidonic acid} Lung tissues and NCI-H292 cells were lysed according to Filgueiras AND POSSMAYer [34] and centrifuged for $5 \mathrm{~min}$ at $1,000 \times g$ to remove debris. Protein concentrations in pellets were measured by using a kit from Pierce (Thermo Scientific, Rockford, IL, USA). Extracts with equivalent protein contents were incubated for $30 \mathrm{~min}$ with $1 \mathrm{~mL}$ vesicles containing 6 nmoles of 1-palmitoyl-2[ $\left[{ }^{14} \mathrm{C}\right]$ arachidonoyl-sn-glycero-3phosphorylcholine $\left(>53 \mathrm{mCi} \cdot \mathrm{mmol}^{-1}\right.$ ) (Perkin-Elmer, Boston, MA, USA) and 4 nmoles of diacylglycerol (Sigma), in the presence of $5 \mathrm{mM} \mathrm{CaCl}$ and $1 \mathrm{mM}$ 2-mercaptoethanol [35]. This assay detects selectively cPLA2 $\alpha$ activity as iPLA2 (calcium independent phospholipase A2) activity does not require calcium, and 2-mercaptoethanol inhibits sPLA2 (secretory phospholipase A2) but not cPLA2 $\alpha$ activity [35]. Then, measurements and calculations of $\mathrm{CPLA} 2 \alpha$ activity were measured [35]. The levels of free arachidonic acid were measured in BAL fluid (BALF) by gas chromatography/mass spectrometry as previously reported [36].

\section{MUC5AC ELISA}

Aliquots from cell lysates or cell cultures were incubated with bicarbonate-carbonate buffer $(50 \mu \mathrm{L})$ at $40^{\circ} \mathrm{C}$ in a 96-well plate (Nalge Nunc International, Rochester, NY, USA) until dry. MUC5AC levels were measured by ELISA using a mouse monoclonal antibody directed against MUC5AC (clone 45 M1, Neomarkers) as previously reported [37]. This antibody is specific for MUC5AC.

\section{Interleukin-8 and PGE2 measurements}

Interleukin (IL)-8 and PGE2 levels in cell cultures were determined using commercial ELISA and EIA kits from R\&D Systems (Minneapolis, MN, USA) and Cayman Chemicals (Ann Arbor, MI, USA).

\section{Western blotting analysis}

Lung tissues and NCI-H292 cells were lysed in lysis buffer (Buffer RLT from Qiagen, Courtaboeuf, France) and RIPA buffer, respectively. Equivalent amounts of proteins per sample were loaded onto $7.5 \%$ Tris/glycine/SDS-polyacrylamide gels. Blots were then incubated for $1 \mathrm{~h}$ at room temperature with 1:200 dilution of a goat antibody specific for human cPLA2 $\alpha$ (sc-454, Santa Cruz Biotechnology, Inc., Santa Cruz, CA, USA) or a 1:1000 dilution of a mouse monoclonal antibody specific for human CFTR (ab2784; Abcam, Cambridge, MA, USA).

\section{Bronchial explants of CF and non-CF patients}

Bronchial explants were obtained at transplantation from 10 adults with CF with F508del mutation and seven non-CF patients with lung cancer (table 2 in the online supplementary material), as previously reported [12]. None of these patients required invasive mechanical ventilation before the lung transplantation procedure. The study conformed to the Declaration of Helsinki and to the rules of the Committee on Human Research of Hôpital Cochin, Paris, France.

\section{Statistical analyses}

We performed comparisons among all groups using ANOVA, and between two subject groups by the two-tailed t-test using SPSS software. Levene's test was used to test the homogeneity of variance. Data are expressed as means \pm SEM and a p-value $<0.05$ was considered significant.

\section{RESULTS \\ $\mathrm{Cftr}^{-/-}$mice exhibit increased pulmonary mucus production and MUC5AC expression}

Histological analyses of lung sections showed a normal structure, no inflammatory cells and no mucus-positive cells in $\mathrm{Cftr}^{+/+}$mice. However, in $\mathrm{Cftr}^{-/-}$mice, increased numbers of mucus-positive cells (fig. 1a-l) were detected compared with $\mathrm{Ctr}^{+/+}$mice (see also mucus scores in fig. $1 \mathrm{~s}, \mathrm{p}<0.05$ ). Intratracheal instillation of $P$. aeruginosa LPS $\left(330 \mu \mathrm{g} \cdot \mathrm{kg}^{-1}\right)$ induced an intense bronchopneumonia (characterised by an accumulation of inflammatory cells inside the bronchial lumen and parenchyma) to a similar extent in the two mouse strains (fig. 1a-1). This dose of LPS $\left(330 \mu \mathrm{g}^{\mathrm{kg}} \mathrm{kg}^{-1}\right)$ has been shown to induce an optimal lung inflammation [30]. No significant differences in PMN counts (fig. 1a in the online supplementary material) and macrophage inflammatory protein-2 concentration (data not shown) were observed in BAL fluids from the two strains. However, LPS increased the numbers of mucuspositive cells (fig. 1a-l) in $\mathrm{Cftr}^{-/-}$compared with $\mathrm{Cftr}^{+/+}$mice (see mucus scores in fig. $1 \mathrm{~s}, \mathrm{p}<0.01$ ). Enhanced mucus production in $\mathrm{Cftr}^{--}$mice was more evident with $\mathrm{AB}$ than with PAS staining. Immuno-histochemical analyses revealed a higher number of MUC5AC-positive cells in the lungs of $\mathrm{Cftr}^{-1}$ compared to $\mathrm{Cftr}^{+/+}$mice (fig. $1 \mathrm{~m}-\mathrm{r}$ ).

\section{$\mathrm{Cftr}^{-/-}$mice display an increased pulmonary cPLA2 $\alpha$ activity and arachidonic acid release}

An increased cPLA2 $\alpha$ activity was observed in lung homogenates of $\mathrm{Cftr}^{-/}$compared with $\mathrm{Cftr}^{+/+}$mice, both in basal conditions $(p<0.05)$ or upon LPS challenge $(p<0.01)$ (fig. $2 a$ in the online supplementary material). This was accompanied by an increase in the levels of free arachidonic acid in $\mathrm{Cftr}^{-1-}$ compared with $\mathrm{Cftr}^{+/+}$mice $(\mathrm{p}<0.05)$ (fig. $2 \mathrm{~b}$ in the online supplementary material). Similar levels of cPLA2 $\alpha$ protein (fig. $2 \mathrm{c}$ in the online supplementary material) were observed in lungs of $\mathrm{Cftr}^{-/-}$and $\mathrm{Cftr}^{+++}$mice, before and after LPS challenge. The specific cPLA2 $\alpha$ inhibitor ATK [29] reduced cPLA2 $\alpha$ activity in lung homogenates by $>80 \%(\mathrm{p}<0.01)$ (fig. $2 \mathrm{~d}$ in the online supplementary material). Thus, the observed increase in PLA2 activity is likely due (in large part) to an enhanced stimulation of $\mathrm{cPLA} 2 \alpha$ activity.

\section{cPLA2 $\alpha$ regulates bronchial mucus production in $\mathrm{Cftr}^{-/-}$ mice}

Intraperitoneal injection of ATK before intratracheal LPS instillation reduced $A B$ staining (fig. $2 a-1$ versus fig. 1a-1) in both $\mathrm{Cftr}^{--}$and normal littermate mice (see mucus scores in 

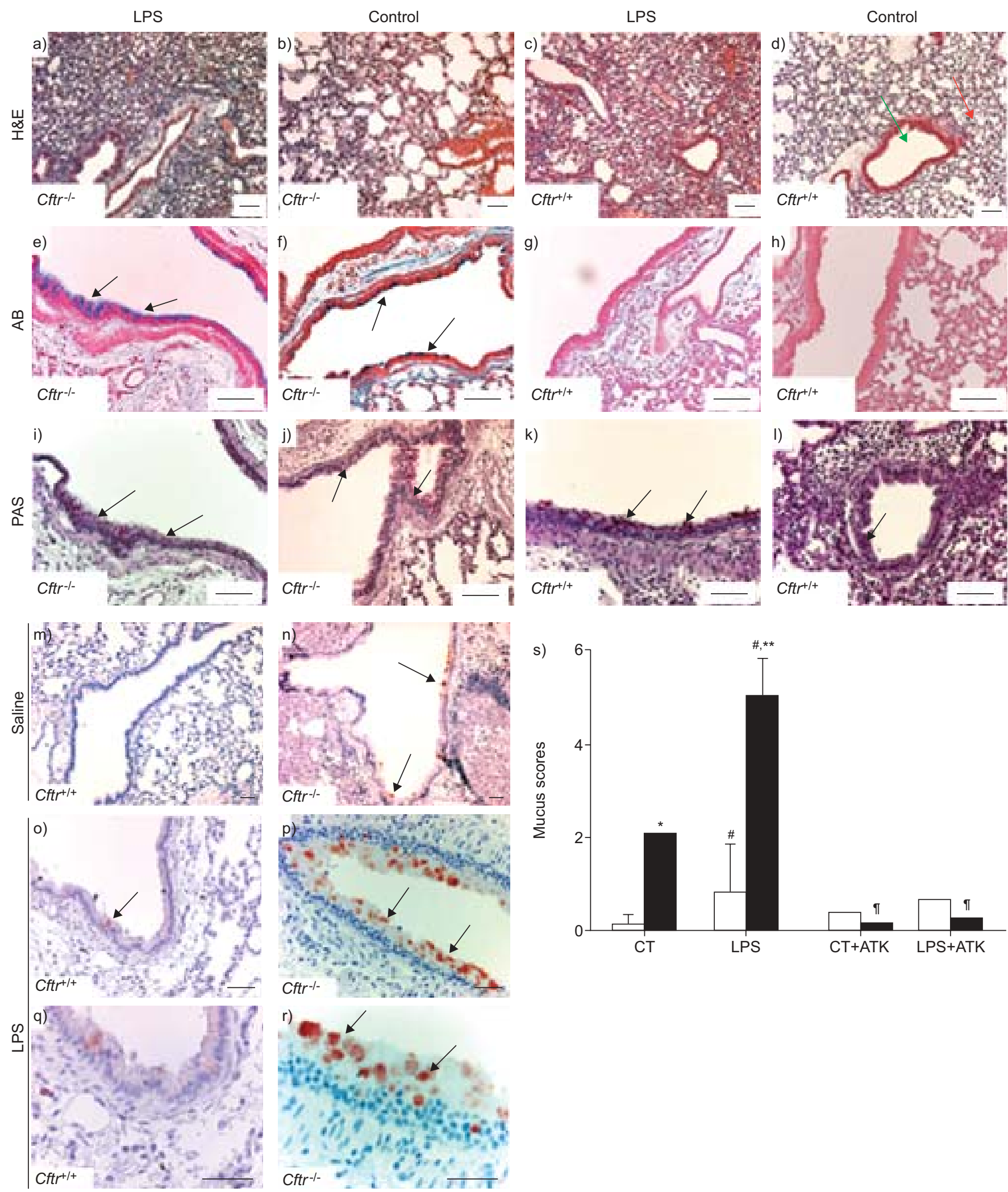

FIGURE 1. Enhanced mucus production in the respiratory tract of cystic fibrosis transmembrane conductance regulator gene (Cftr $)^{-/-}$mice. a-l) Histological analyses. $\mathrm{Cftr}^{+/+}$and $\mathrm{Cftr}^{-/-}$mice received intra-tracheal instillation of saline alone or containing lipopolysaccharide (LPS) (330 $\left.\mu \mathrm{gg} \cdot \mathrm{kg}^{-1}\right)$ and analyses were performed 4 days later. a-d) Haematoxylin/eosin (H\&E) staining of paraffin sections of lung tissues from mice treated with saline (b and d) or LPS ( $a$ and c). Histopathological examination of lung sections from mice treated with saline showed a normal structure and no inflammatory cells ( $b$ and d), in contrast to lungs from LPS-treated mice, which revealed bronchopneumonia (a and $c$ ). Bronchopneumonia is characterised by accumulation of inflammatory cells inside the bronchial lumen and parenchyma. e-h) Alcian Blue (AB) staining of paraffin sections of lungs. 
FIGURE 1. (cont.) No mucus-positive cells were detected in lung sections from saline-treated $\mathrm{Cftr}^{+/+}$mice (h). A moderate staining was detected in saline-treated $\mathrm{Cttr}^{-/}$mice (f). In LPS-treated mice, mucus-positive cells were detected in $\mathrm{Cftr}^{-1}$ mice (e) at higher number than in $\mathrm{Cftr}^{+/+}$mice (g). i-l) Periodic acid-Schiff (PAS) staining. Mucus positive cells were detected with this staining both in $\mathrm{Cftr}^{+/+}$( $\mathrm{k}$ and $\mathrm{l}$ ) and $\mathrm{Cftr} \mathrm{r}^{-/}$( $\mathrm{i}$ and $\left.\mathrm{j}\right)$ mice. No differences were observed between the two mouse strains either after saline (j and $)$ or LPS (I and k) treatment. Mucus-positive cells are indicated by arrows. AB-positive cells are in blue and PAS-positive cells are in magenta (see AB and PAS panels, respectively). Green arrow shows bronchi and red arrow shows alveoli (see H\&E panels). Scale bars $=50 \mu \mathrm{m}$. m-r) Immunohistochemical analyses. Immunohistochemical detection of MUC5AC was performed with an anti-MUC5AC antibody on lung sections from $\mathrm{Cftr}^{+/+}$and $\mathrm{Cftr}{ }^{-/}$mice. Mice were treated with saline $(\mathrm{m}$ and $\mathrm{n}$ ) or LPS (o-r) and analyses performed 4 days later. No staining was observed in saline (m) or LPS-treated (o and q) $\mathrm{Cftr}^{+/+}$mice. Saline-treated $\mathrm{Cft}^{-/-}$mice (n) showed little MUC5AC staining which increased after LPS instillation ( $p$ and $r$ ). MUC5AC-positive staining was associated with goblet cells ( $p$ and $r$ ). Scale bars $=50 \mu \mathrm{m}$. $s$ ) Mucus scores were determined based on AB-staining of lung sections shown

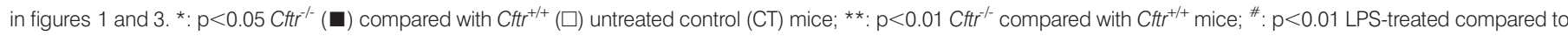
saline-treated mice; $" \mathrm{p}<0.01$ arachidyl trifluoromethyl ketone (ATK)-treated compared to untreated mice.

fig. 1s; $\mathrm{p}<0.01)$. ATK also abrogated the number of MUC5AC positive cells (fig. $2 \mathrm{~m}-\mathrm{p}$ ). However, ATK had no effect on the inflammatory status as shown by histological analyses (fig. 2a-l) and PMN counts in BAL (fig. $1 \mathrm{~b}$ in the online supplementary material). In contrast to cPLA $2 \alpha^{+/+}$mice, no detectable mucuspositive cells were observed in cPLA2 $\alpha^{-/-}$mice, both under basal conditions and after LPS instillation (fig. 3a-1 and fig. 3s; $\mathrm{p}<0.01$ ). Intratracheal instillation of LPS induced an intense bronchopneumonia (fig. 3a-l). This was accompanied by increased PMN counts in BAL (fig. 3 in the online supplementary material). These processes were observed at similar intensities in wild-type and cPLA2 $\alpha^{-1-}$ mice. Intratracheal instillation of arachidonic acid to $\mathrm{C} 57 / \mathrm{Bl6}$ wild-type mice increased the number of mucus-positive cells (fig. $3 \mathrm{~m}-\mathrm{r}$ and $\mathrm{t} ; \mathrm{p}<0.01$ ). However, arachidonic acid had no effect on PMN infiltration in lung tissues as shown by $\mathrm{H} \& \mathrm{E}$ staining (fig. $3 \mathrm{~m}-\mathrm{r}$ ).

\section{CF patients exhibit an increased bronchial CPLA2 $\alpha$ activity}

A marked immuno-staining of the phosphorylated (active) form of cPLA2 $\alpha$ was observed in all sections from CF compared with non-CF patients. Positive staining was observed in the nuclei and plasma membranes of airway epithelial cells. Infiltrating inflammatory cells (e.g. neutrophils) were also positively stained (fig. $4 a-c)$. Higher levels of cPLA2 $\alpha$ activity were found in homogenates of bronchial explants from CF compared with non-CF patients (fig. $4 \mathrm{~d} ; \mathrm{p}<0.01$ ). This activity was significantly reduced by treating homogenates from CF patients with ATK $\left(8,422 \pm 300\right.$ versus $2,415 \pm 187 \mathrm{dpm} \cdot \mathrm{mg}^{-1}$, mean $\pm \mathrm{SEM}, \mathrm{n}=6$, in control and ATK-treated homogenates, respectively; $\mathrm{p}<0.01$ ).

\section{CFTR modulates MUC5AC expression in NCI-H292 cells via a cPLA2 $\alpha$-dependent mechanism}

We examined the role of CPLA2 $\alpha$ and CFTR in MUC5AC expression in the human lung epithelial cell line NCI-H292, which expresses both CFTR and cPLA2 $\alpha$ (fig. $4 a$ and $b$ in the online supplementary material). LPS, TGF- $\alpha$ and PMA induced an increase of MU5AC levels in cell lysates (fig. 5a and b) $(\mathrm{p}<0.01)$. PMA is known to induce MUC5AC expression in NCI-H292 cells via matrix metalloprotease-mediated release of TGF- $\alpha$ [38]. MUC5AC levels were reduced by cPLA2 $\alpha$ inhibitors MAFP and Pyrrolydine- 1 (fig. $5 b)(p<0.01)$, and enhanced by arachidonic acid (fig. $5 \mathrm{c}) \quad(\mathrm{p}<0.01)$. Neither cPLA2 $\alpha$ inhibitors nor arachidonic acid interfered with IL-8 secretion (data not shown).

Silencing of CFTR expression by siRNA reduced the levels of CFTR protein by $72 \pm 7.5 \%(\mathrm{p}<0.01)$ and $62 \pm 5.5 \%(\mathrm{p}<0.05)$ compared with negative siRNA-treated and with untreated cells, respectively (fig. $4 \mathrm{~b}$ and $\mathrm{c}$ in the online supplementary material). This led to an increased cPLA2 activity (fig. 6a) $(\mathrm{p}<0.01)$ and PGE2 release (fig. 5a in the online supplementary material). This was accompanied by increased MUC5AC levels in cell extracts (fig. $6 b)(p<0.01)$ and culture media (fig. $5 b$ in the online supplementary material), both of which were reduced by MAFP. In contrast, pre-treating cells with the specific CFTR functional inhibitor $\mathrm{CFTR}_{\text {inh }}-172$ [39] failed to increase MUC5AC expression and even decreased it (fig. 6c). As a positive control, we showed that $\mathrm{CFTR}_{\mathrm{inh}}-172$ induced an increased IL-8 secretion under LPS $(\mathrm{p}<0.05)$ and PMA $(\mathrm{p}<0.01)$ stimulation (fig. $6 \mathrm{~d})$, which is considered as evidence of effective inhibition of CFTR function by CFTR $_{\text {inh }}-172$. At this concentration $\mathrm{CFTR}_{\mathrm{inh}}-172$ has been shown to inhibit specifically the CFTR Cl-function without interfering with the activity of other Cl- channels [39]. We conclude that the level of CFTR protein expression, but not CFTR transport activity, regulates cPLA2 $\alpha$ activity, and subsequently MUC5AC expression.

\section{DISCUSSION}

The present study shows that $\mathrm{Cftr}^{-1}$ mice exhibit enhanced bronchial mucus production which is exacerbated by $P$. aeruginosa LPS. This occurs through a process involving, at least in part, an up-regulation of cPLA2 $\alpha$ activity. In support of this, we showed that mucus production was abolished by a cPLA2 $\alpha$ null mutation or by a specific cPLA2 $\alpha$ inhibitor. Airway explants from CF patients also showed enhanced cPLA2 $\alpha$ activity mainly located in epithelial cells that have been shown to exhibit increased MUC5AC expression [12]. In a cell model, we showed that cPLA2 $\alpha$ activity and MUC5AC expression increase after reduction of CFTR expression. This MUC5AC expression was abrogated by cPLA2 $\alpha$ inhibition. However, cPLA2 $\alpha$ appears to play a minor role in LPS-induced inflammation in our experimental models. Indeed, neither cPLA2 $\alpha$ knock-out nor its pharmacological inhibition had any effect on PMN influx in the airways, or on IL-8 expression in epithelial cells. Although our studies clearly indicate that cPLA2 $\alpha$ plays a key role in mucus production, the implication of other PLA2 in this process cannot be excluded. Indeed, it has been shown that secreted PLA2 stimulate mucus secretion in ferret trachea [40].

Our studies demonstrated an impact of CFTR dysfunction on mucus production in airway epithelial cells, both in vitro and in vivo, using three different methods (Immuno-histochemistry, histological staining and ELISA). Our findings showing that $\mathrm{Cftr}^{-1}$ mice exhibit exacerbated bronchial mucus production is in agreement with a previous report [41] although this was contested in another one [42]. Differences in animal husbandry, experimental protocols or genetic background may explain this apparent discrepancy. 

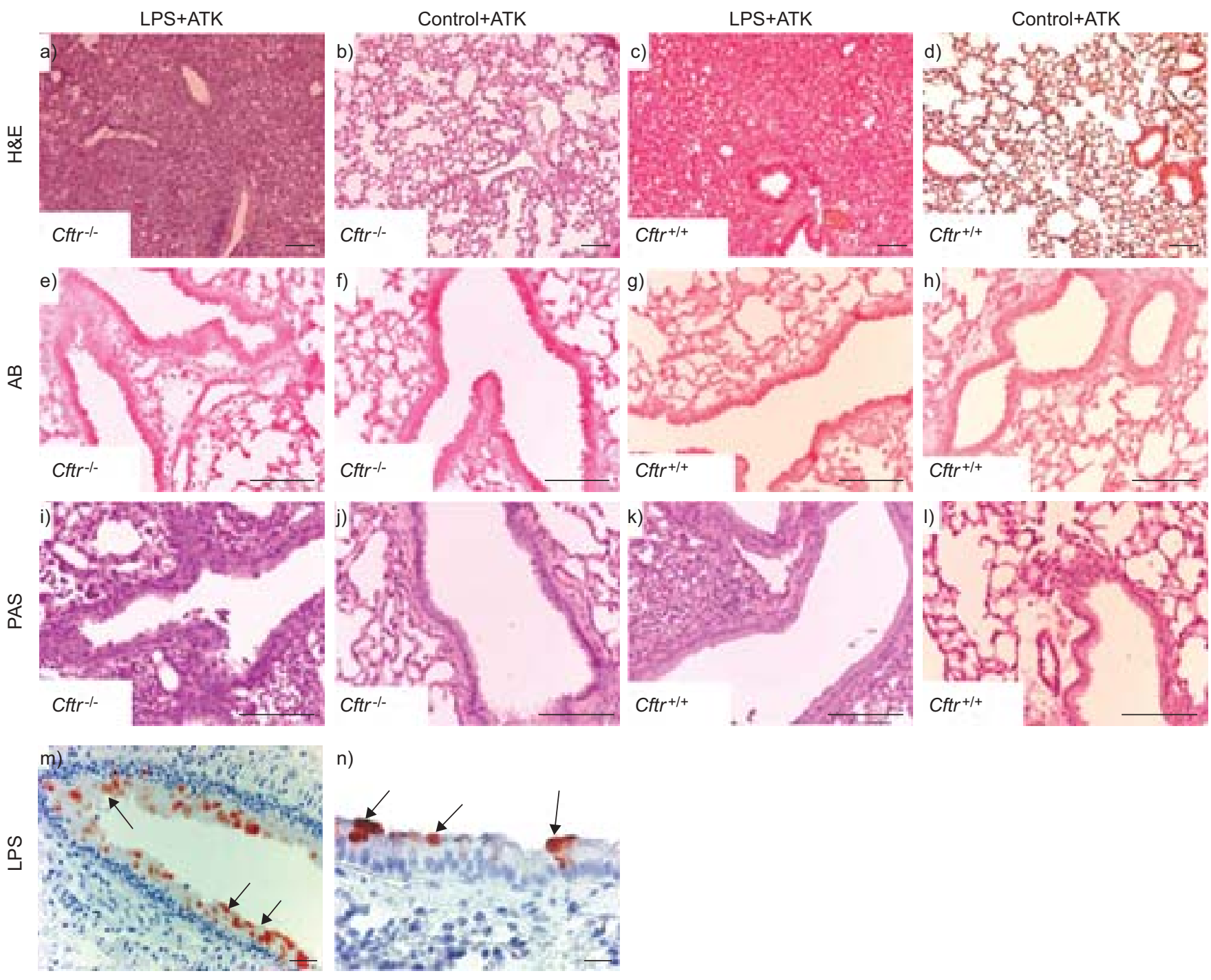

n)
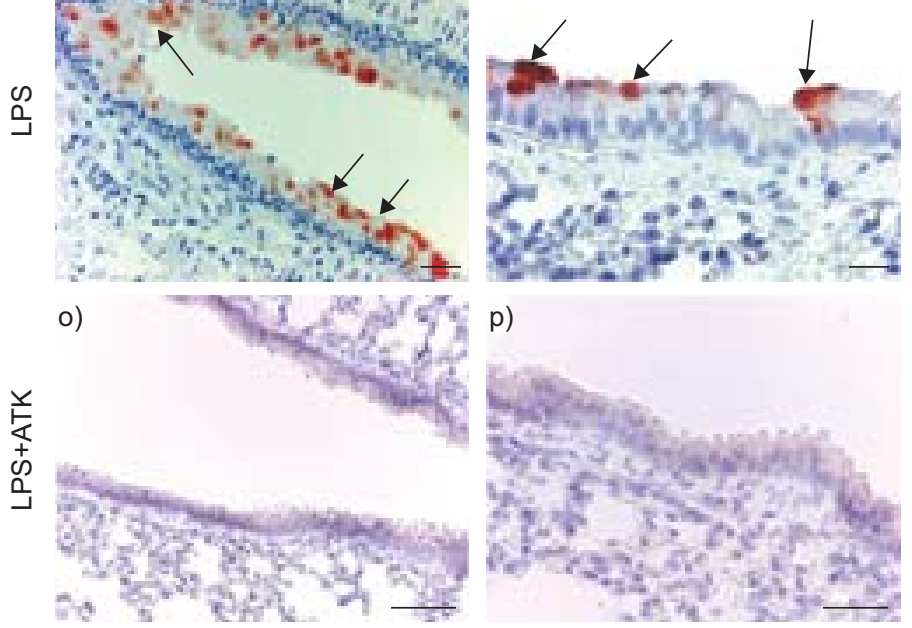

p)

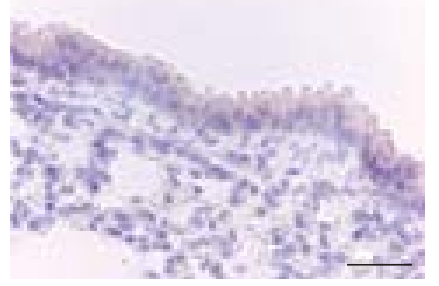

FIGURE 2. Inhibition of mucus production by a cytosolic phospholipase $2 \alpha$ inhibitor. a-l) Histological analyses compared with figure 1 . Cystic fibrosis transmembrane conductance regulator $(\mathrm{Ctr})^{+/+}$and $\mathrm{Cftr}^{-1-}$ mice were pretreated intraperitonealy with arachidonyl trifluoromethyl ketone (ATK) $\left(20 \mathrm{mg} \cdot \mathrm{kg}^{-1}\right)$ or vehicle. Mice received intratracheal lipopolysaccharide (LPS) instillation as detailed in the Materials and Methods section. a-d) Haematoxylin/eosin (H\&E) staining of paraffin sections of lung obtained from saline-treated ( $b$ and d) or LPS-treated mice ( $a$ and c) mice. The histopathological examination of saline-treated mice sections showed a normal structure and no inflammatory cells ( $b$ and $d$ ). Lung sections from LPS-treated mice ( $a$ and $c$ ) displayed an accumulation of neutrophils. e-h) Alcian blue (AB) and i-I) periodic acid-Schiff (PAS) staining of lung sections. No AB- or PAS-positive cells were detected in lung sections from either $\mathrm{Cftr}^{+/+}$or $\mathrm{Cftr}^{-1-}$ mice treated with ATK. Scale bars $=50 \mu \mathrm{m}$. The solvent of ATK, ethanol, had no effect (data not shown). m-p) Immunohistological analyses of LPS-induced MUC5AC expression in ATK-treated Cftr ${ }^{-1}$ mice. Cftr ${ }^{-1-}$ mice received either ATK or its solvent ethanol alone before LPS instillation. ATK treatment reduced the number of MUC5AC-positive cells (o and $\mathrm{p}$ ) compared with ethanol-treated mice ( $\mathrm{m}$ and $\mathrm{n}$ ) in which strong expression of MUC5AC is observed in goblet cells. Omission of the primary antibody or incubation with an irrelevant antibody showed no signal (data not shown). Scale bars $=50 \mu \mathrm{m}$.

The enhanced cPLA2 $\alpha$ activity in $\mathrm{Cftr}^{-1}$ mouse lung and human CF bronchial explants observed in the present work is in agreement with previous studies in human cell lines bearing the F508del mutation [43, 44]. In these cells, an abnormal cPLA2 $\alpha$ activity has been suggested to be a direct consequence of CFTR alteration. One plausible scenario is that CFTR acts as 

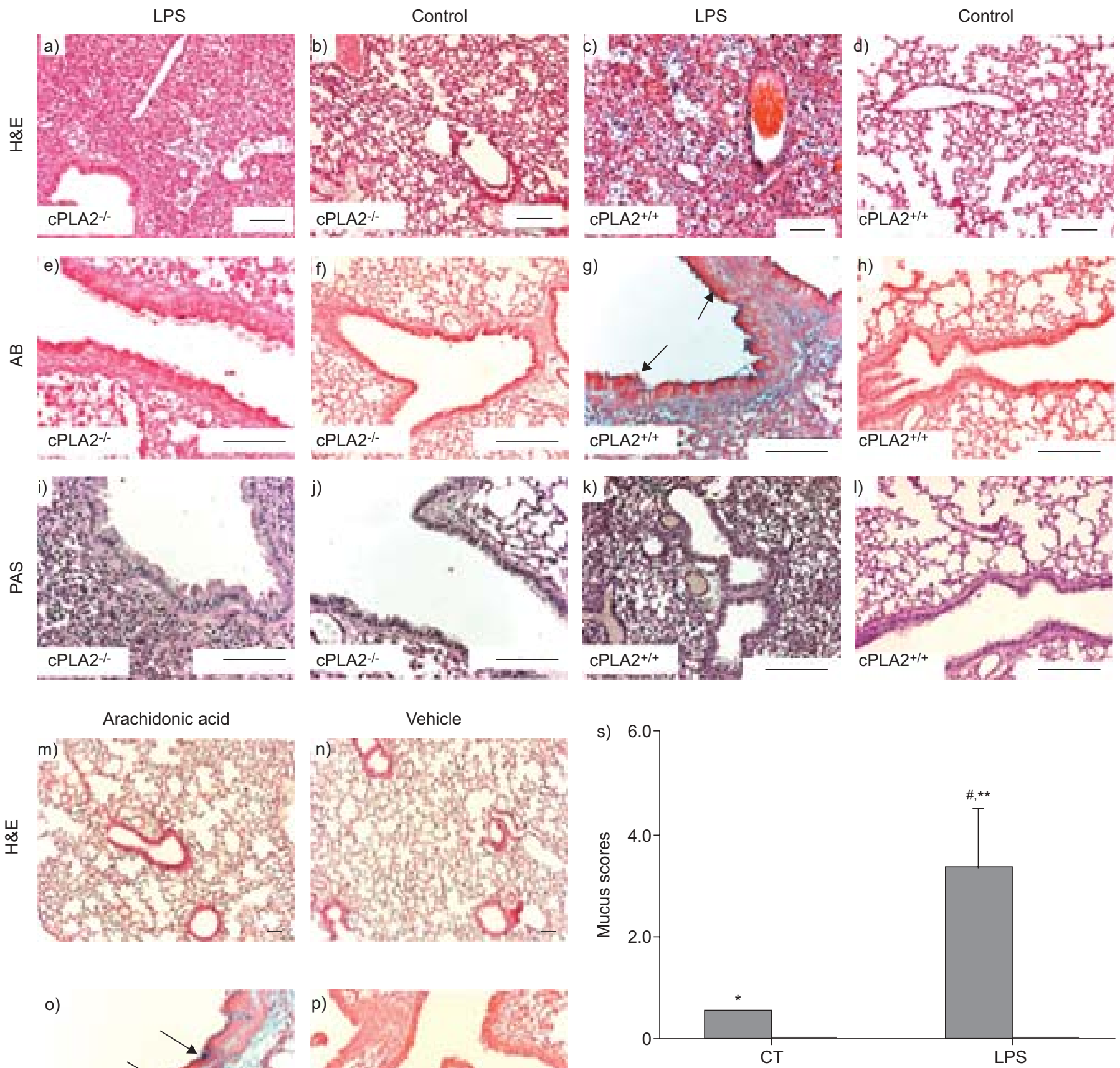

高
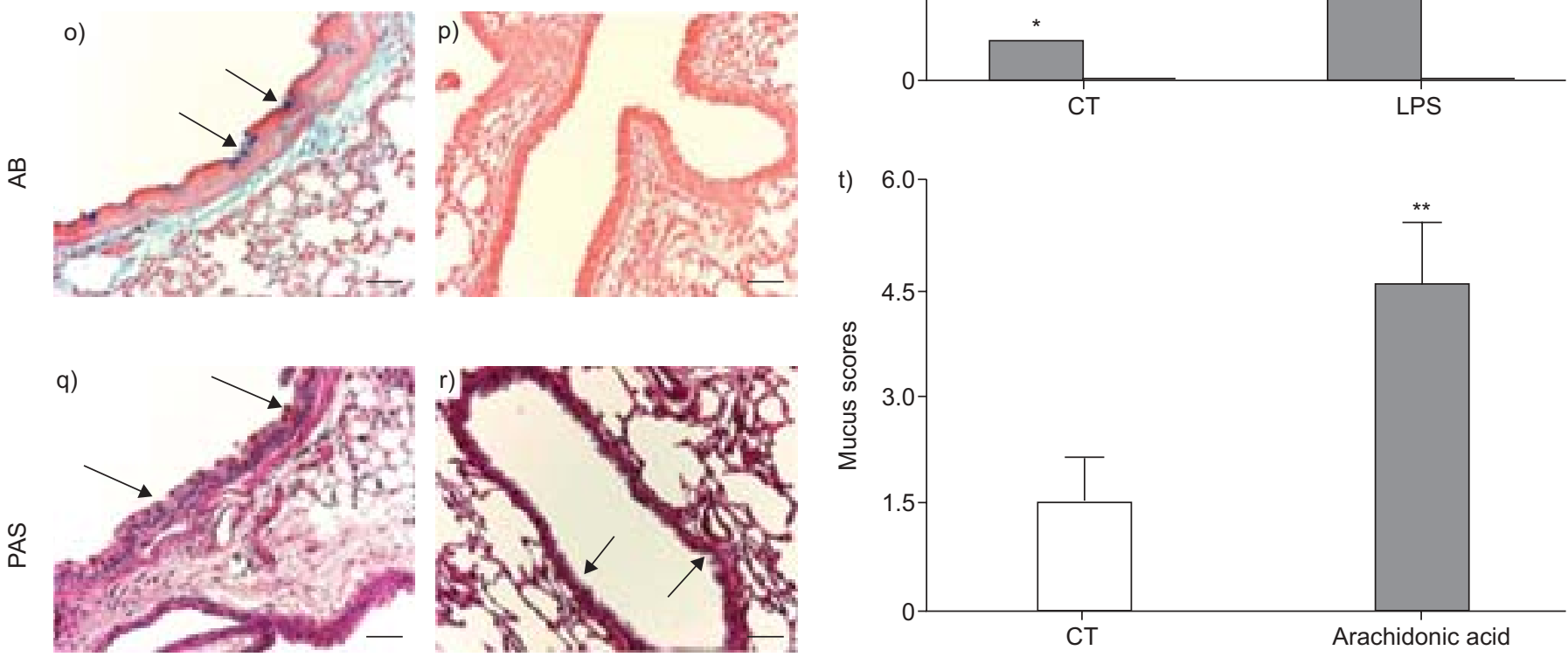
FIGURE 3. Effect of cytosolic phospholipase A2 (CPLA2) knock down and arachidonic acid instillation on bronchial mucus production. a-I). Histological analyses of cPLA2 $\alpha^{-/}$and cPLA2 $\alpha^{+/+}$mice. Mice were treated intratracheally with either saline or lipopolysaccharide (LPS) and analyses were performed 4 days later. a-d) Haematoxylin/ eosin (H\&E) staining of lung paraffin sections from mice treated with either saline or LPS. Saline-treated mice showed normal structure and no inflammatory cells (b and d). Lung sections from LPS-treated mice (a and c) showed bronchopneumonia with accumulation of neutrophils. e-h) Alcian blue (AB)- and i-l) periodic acid-Schiff (PAS)staining of lung sections. No AB-positive cells were detected in the lungs from saline-or LPS-treated cPLA2 $\alpha^{-1-}$ mice (e and f). Mucus-positive cells were detected in LPStreated $(\mathrm{g})$, but not in saline-treated (h) CPLA2 $\alpha^{+/+}$mice. No differences were observed by PAS-staining between the two mice strains after either saline ( $\mathrm{j}$ and $\left.\mathrm{l}\right)$ or LPS ( $\mathrm{i}$ and $\mathrm{k}$ ) treatment. Scale bars $=50 \mu \mathrm{m} . \mathrm{m}-\mathrm{r}$ ) Histological analyses of arachidonic acid-treated mice. Wild-type mice were instilled intratracheally with either arachidonic acid (m, o and q) or its solvent alone ( $0.25 \%$ bovine serum albumin; $n, p$ and $r)$ and sacrificed 4 days later. $m$ and $n)$ H\&E staining of lung paraffin sections. Solvent-treated mice show a normal structure and no inflammatory cells. Panel o shows mucus-positive cells (Alcian blue (AB)-staining) in lung tissue from arachidonic acid-treated mice. No positive cells were detected in solvent-treated mice (p). Periodic acid-Schiff (PAS)-staining shows almost a similar number of positive cells in solvent- and arachidonic acid -treated mice ( $\mathrm{q}$ and r). Mucus cells are identified by arrows. Scale bars $=50 \mu \mathrm{m}$. s) Mucus score of cPLA2 $\alpha^{-/-}$and $\mathrm{CPLA} 2 \alpha^{+/+}$mice. Scores were determined based on AB-staining of lung

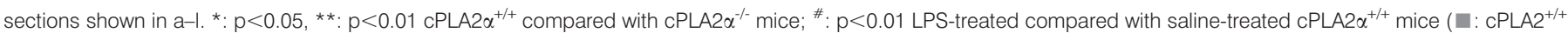
- : $\mathrm{CPLA}^{--}$).t) Mucus scores of arachidonic acid-treated mice. Scores were determined based on AB-staining from lung sections shown in a-l and are expressed as arbitrary units. ${ }^{* *} \mathrm{p}<0.01$ arachidonic acid -treated versus control (CT) mice.

an inhibitor of cPLA2 $\alpha$ activity through a domain with high homology to annexin-1 [45], a cPLA2 $\alpha$ inhibitory protein [46, 47]. Consequently, the conditions that reduce CFTR levels would be expected to enhance cPLA2 $\alpha$ activity. It is established that F508del mutation leads to endoplasmic reticulum retention and rapid degradation of CFTR [48, 49]. The present study
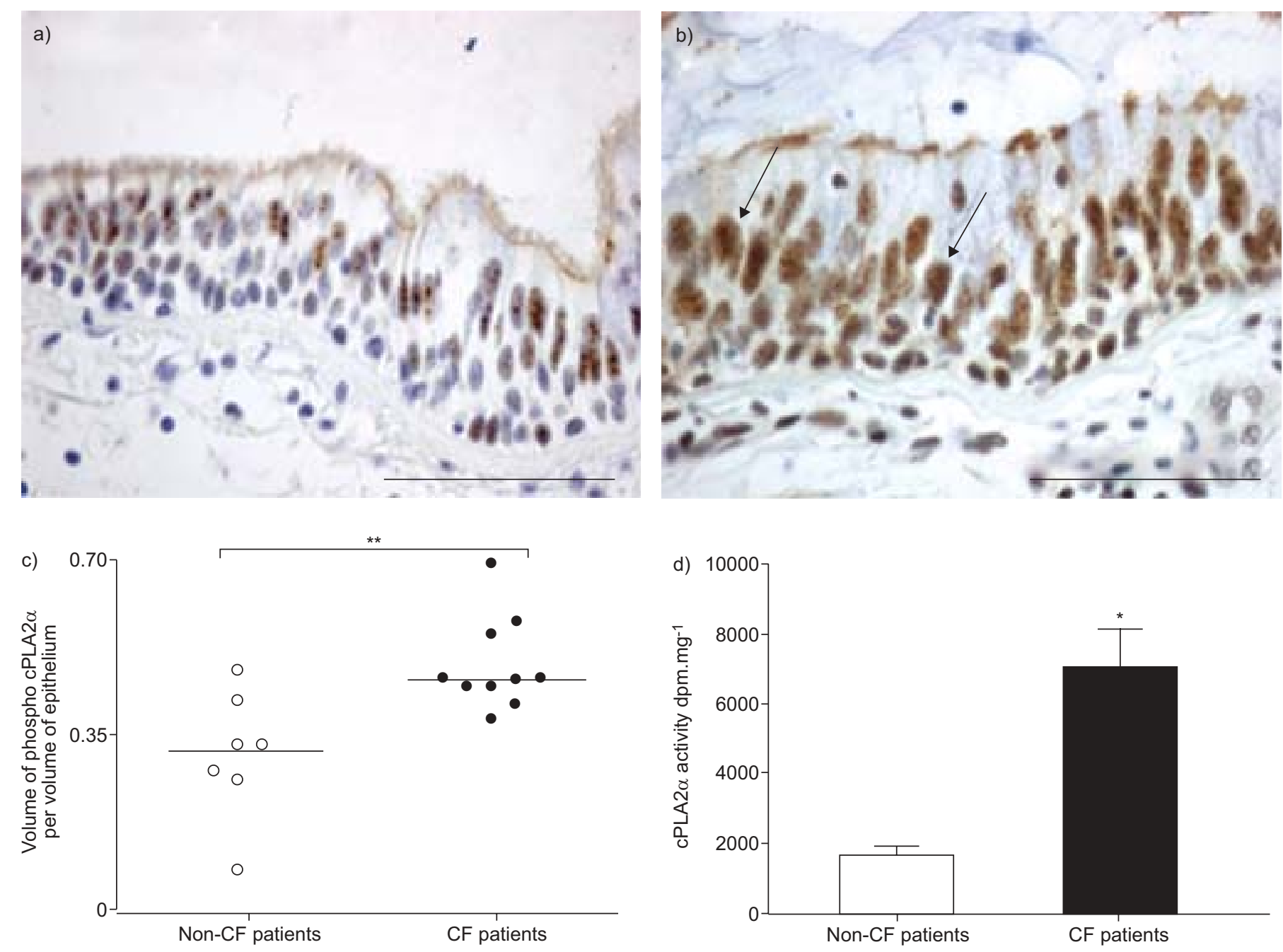

FIGURE 4. Enhanced cytosolic phospholipase A2 $\alpha$ (CPLA2 $\alpha$ ) activation in bronchial explants from cystic fibrosis (CF) patients. a and b) cPLA2 $\alpha$ phosphorylation was analysed by immuno-histochemistry in sections of bronchial explants from seven non-CF (a) and 10 CF patients (b). Representative photomicrographs of staining are shown with arrows. c) Score analysis of positive cells, performed on non-CF $(O)$ and CF $(\bullet)$ patients. Strong immunostaining was observed in the nuclei and plasma membranes of airway epithelial cells from CF patients. d) CPLA2 $\alpha$ activity was measured in homogenates of bronchial explants from CF ( $\square$ ) and non-CF ( $\square$ ) patients. Omission of the primary antibody or incubation with an irrelevant antibody showed no signal (not shown).*: $p<0.05$; $* *$ : $p<0.01$ CF versus non-CF patients. 

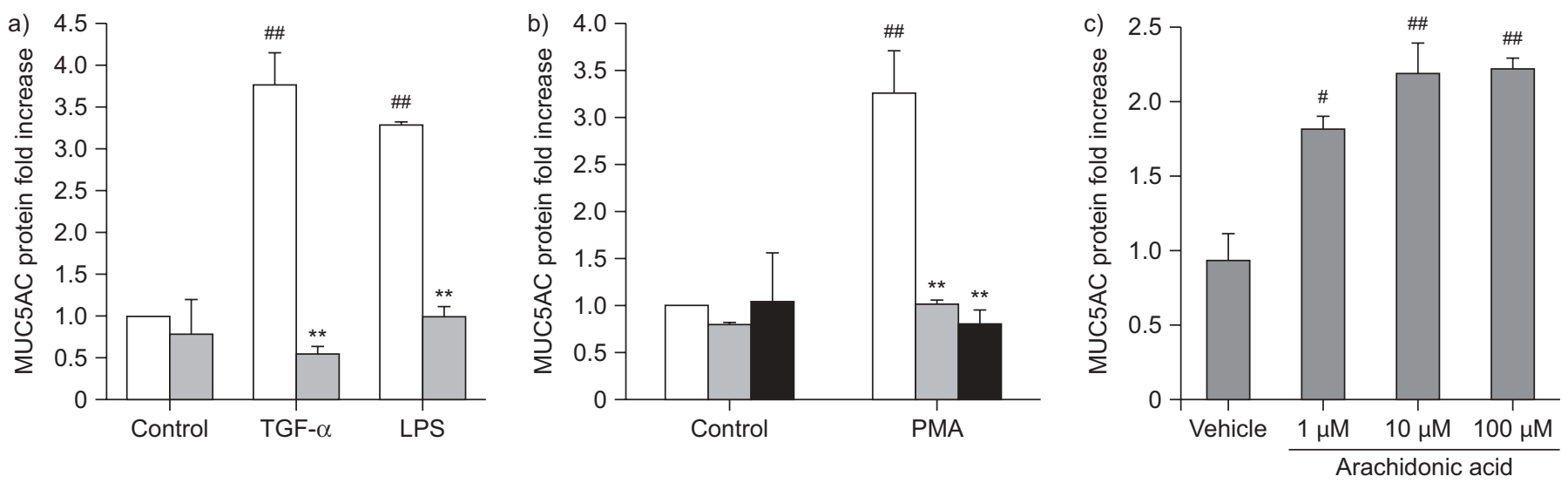

FIGURE 5. Role of cytosolic phospholipase A2 $\alpha$ (CPLA2 $\alpha$ ) in MUC5AC expression in NCI-H292 cells. a and b) Cells were incubated with methyl arachidonyl fluorophosphonate $(\square)(10 \mu \mathrm{M})$, pyrrolidine-1 ( $\square)(5 \mu \mathrm{M})$ or their vehicle (dimethyl sulfoxide $\square)$, then stimulated for $24 \mathrm{~h}$ with lipopolysaccharide (LPS) $\left(10 \mu \mathrm{g} \cdot \mathrm{mL}^{-1}\right)$ or transforming growth factor (TGF)- $\alpha(20 \mathrm{nM})(\mathrm{a})$, or phorbol myristate acetate (PMA) (30 nM) (b). c) Cells were incubated for $24 \mathrm{~h}$ with the indicated concentrations of arachidonic acid. MUC5AC levels were measured in cell lysates. ${ }^{\#}: p<0.05$ versus unstimulated cells; ${ }^{\# \#}: p<0.01$ versus unstimulated cells.

shows that CFTR silencing increases cPLA2 $\alpha$ activity in epithelial cells. In a recent work [20], we presented evidence that CPLA2 $\alpha$ and CFTR form a complex, apparently through
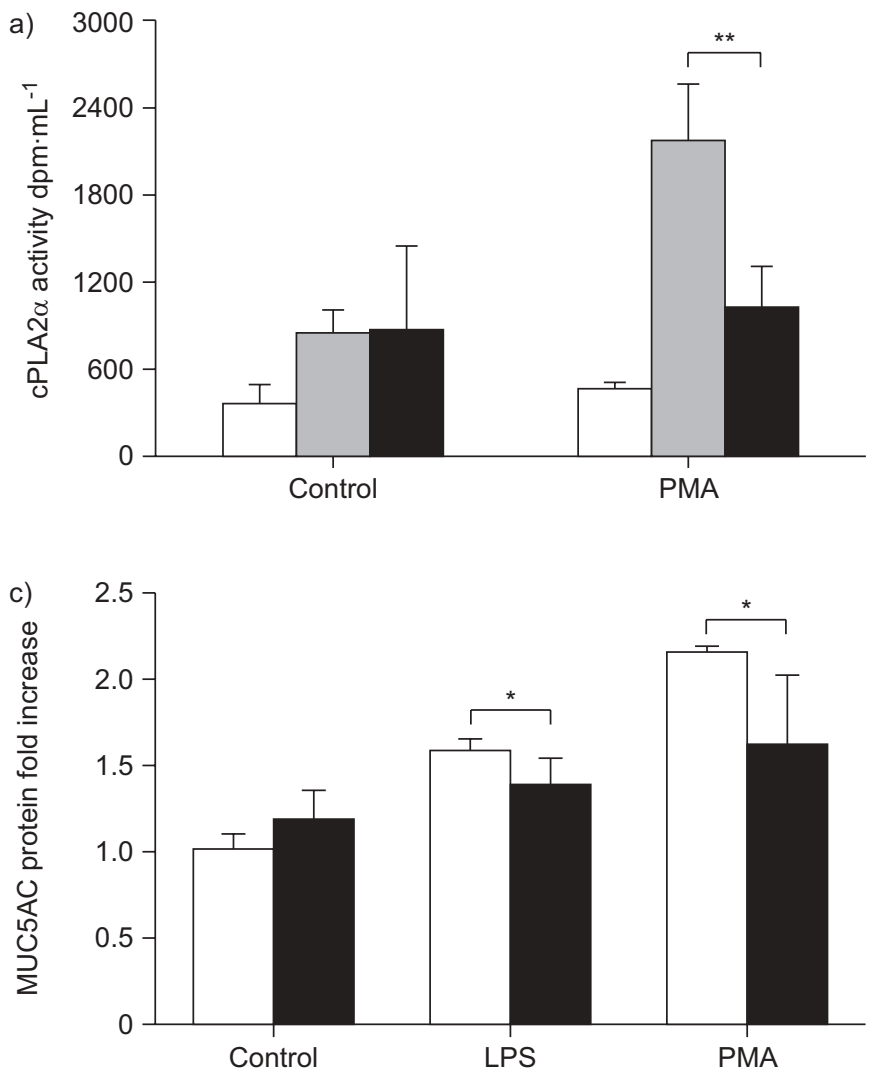

interaction with S100A10/annexin-1 and that the integrity of this complex may affect cPLA2 $\alpha$ activity. This is in agreement with previous reports demonstrating the ability of CFTR to
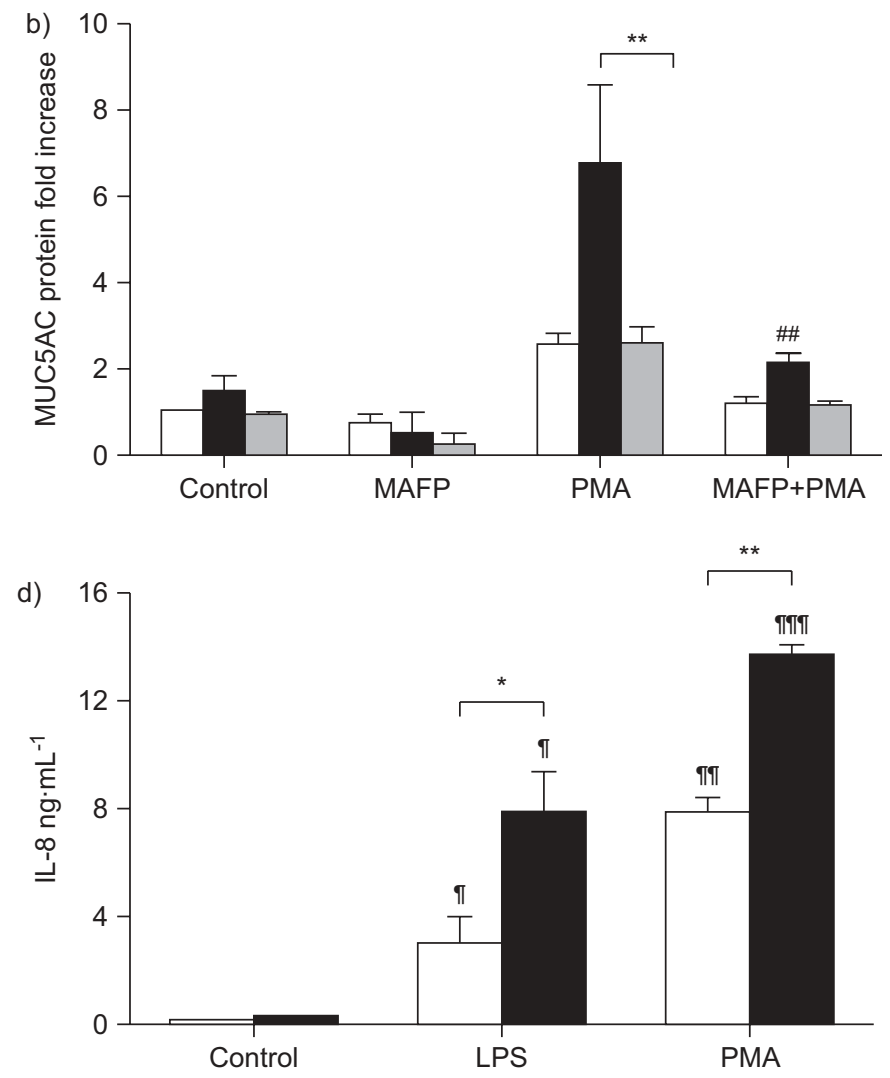

FIGURE 6. Effect of cystic fibrosis transmembrane conductance regulator (CFTR) on cytosolic phospholipase A2 $\alpha$ (CPLA2 $\alpha$ ) activity and MUC5AC expression in NCI$\mathrm{H} 292$ cells. $\mathrm{a}$ and b) Cells were subjected to CFTR siRNA and pre-incubated with methyl arachidonyl fluorophosphonate (MAFP) before stimulation with phorbol myristate acetate (PMA) $(30 \mathrm{nM})$, then CPLA2 $\alpha$ activity (a) and MUC5AC concentrations (b) were measured $2 \mathrm{~h}$ and $24 \mathrm{~h}$ later, respectively ( $\square$ : untreated; $\square$ : siCFTR; $\mathbf{\square}$ : negative siRNA.). c and d) After $1 \mathrm{~h}$ incubation with Inh-172 (10 $\mu \mathrm{M})$, cells were stimulated for $24 \mathrm{~h}$ with PMA (30 nM). MUC5AC (c) and interleukin (IL)-8 (d) levels were measured in

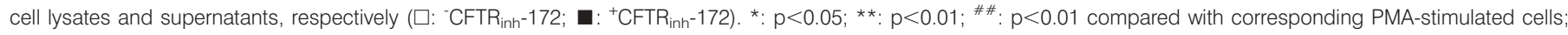

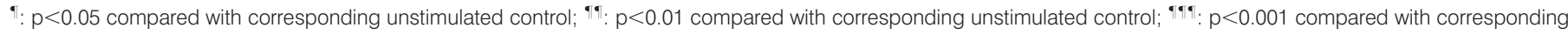
unstimulated control. 
form a complex with annexins II [50] and V [51]. Decreased annexin-1 levels have been reported in a mouse model of asthma [52] with a parallel stimulation of CPLA2 $\alpha$ activity. The expression of annexin-1 is strongly diminished in nasal cells from CF patients, as well as in lung of $\mathrm{Cftr}^{-/}$mice [53]. Based on these reports and our findings that $\mathrm{CPLA} 2 \alpha$ activity is increased in lungs of $\mathrm{Cftr}^{-/}$mice and CF patients, we hypothesise that alteration of levels of one of the components forming this putative complex might impact cPLA2 $\alpha$ activity. Whether this activity is increased in CF epithelial cells as a consequence of alteration of the levels of either CFTR or annexin-1, or both, remains to be elucidated.

We also showed that the CFTR functional inhibitor $\left(\mathrm{CFTR}_{\mathrm{inh}}{ }^{-}\right.$ 172) failed to induce MUC5AC expression in NCI-H292 cells, suggesting that CFTR transport function may not play a major role in MUC5AC expression in this cell model. We suggest that in addition to the effects of CFTR chloride transport function on mucus properties [14], reduction of CFTR levels may modulate MUC5AC expression via a cPLA2 $\alpha$-dependent mechanism. The fact that cPLA2 $\alpha$ inhibition abrogates PMA- and TGF- $\alpha$ induced MUC5AC expression suggests that epidermal growth factor receptor (EGFR)-mediated mucus production occurs, at least in part through cPLA $2 \alpha$ activation. Indeed, PMA is known to induce MUC5AC expression in NCI-H292 cells via matrix metalloprotease-mediated release of TGF- $\alpha$ and EGFR activation [38].

The stimulatory effect of CFTR transcriptional silencing on cPLA2 $\alpha$ activity and MUC5AC expression in epithelial cells suggests that MUC5AC expression in $\mathrm{Cftr}^{-/}$mice may occur in epithelial cells through an autocrine modulation of cPLA2 $\alpha$. Alternatively, MUC5AC induction can occur in goblet cells by a paracrine stimulation by aracgidonic acid released from other epithelial cells. We hypothesise that cPLA2 $\alpha$ may play a role in mucus overproduction during the episodes of $P$. aeruginosa infection in CF patients. Indeed, we showed that: 1) cPLA2 $\alpha$ mediates $P$. aeruginosa LPS-induced mucus overproduction in $\mathrm{Cftr}^{-/}$mouse lungs, 2) this enzyme plays a role in MUC5AC expression in CFTR-deficient human bronchial epithelial cells and 3) cPLA2 $\alpha$ activity increases in bronchial explants from CF patients. It should be stressed that study of non-infected lower airway tissues from living CF subjects is still a major challenge, since most patients will have chronic airway infection/colonisation during the course of the disease. Thus, although bronchial explants do not reflect basal state of these airways, it accurately reflects the in vivo state of airways in chronically infected/inflamed CF airways. Therefore, although our findings suggest a role for $\mathrm{CPLA} 2 \alpha$ in increased mucus production in CF patients, this increase can also be a secondary response to inflammation.

We conclude that reduction of CFTR expression in CF lungs leads to an enhanced activation of $\operatorname{cPLA} 2 \alpha$, which in turn induces mucus overproduction. Induction of mucus production by cPLA $2 \alpha$ may contribute to the mucus-related pathology seen in CF. A pharmacological approach based on the use of a CPLA2 $\alpha$ inhibitor attenuated mucus overproduction in both human epithelial cells and in $\mathrm{Cftr}^{-/}$mice. We propose a potential therapeutic role for $\mathrm{CPLA} 2 \alpha$ inhibitors in reducing mucus accumulation in $\mathrm{CF}$.

\section{SUPPORT STATEMENT}

This work was supported in part by a Contrat de Recherche with the French Associations "Vaincre la Mucoviscidose" and DARRI, Institut Pasteur. F. Dif was supported by "Vaincre la Mucoviscidose". J. Aarbiou and R. Buijs-Offerman (Erasmus MC, Cell Biology Dept, Rotterdam, The Netherlands) were supported by grants STW 6565 and EU FP6IMPROVED PRECISION LSHB-CT-2004-005213.

\section{STATEMENT OF INTEREST}

None declared.

\section{ACKNOWLEDGEMENTS}

The authors would like to thank V. Balloy (Unite de Défense Innée et Inflammation/Unité INSERM U. 874, Institut Pasteur, Paris, France) for her helpful assistance for animal instillations. We are grateful to $\mathrm{M}$. Huerre (Unité de Recherche et d'Expertise Histotechnologie et Pathologie, Institut Pasteur) for expert advice and criticisms and P. Ave and S. Bergère (Unité de Recherche et d'Expertise Histotechnologie et Pathologie, Institut Pasteur) for help on histological analyses. M. Wilke (Erasmus MC, Biochemistry Dept, Rotterdam, The Netherlands) and R. Buijs-Offerman (Erasmus MC, Cell Biology Dept) are acknowledged for assistance in preparing the lung tissues and BALF samples.

\section{REFERENCES}

1 Cheng SH, Gregory RJ, Marshall J, et al. Defective intracellular transport and processing of CFTR is the molecular basis of most cystic fibrosis. Cell 1990; 63: 827-834.

2 Doring G, Gulbins E. Cystic fibrosis and innate immunity: how chloride channel mutations provoke lung disease. Cell Microbiol 2009; 11: 208-216.

3 Balough K, McCubbin M, Weinberger M, et al. The relationship between infection and inflammation in the early stages of lung disease from cystic fibrosis. Pediatr Pulmonol 1995; 20: 63-70.

4 Khan TZ, Wagener JS, Bost T, et al. Early pulmonary inflammation in infants with cystic fibrosis. Am J Respir Crit Care Med 1995; 151: 1075-1082.

5 Wilson JM, Collins FS. Cystic fibrosis. More from the modellers. Nature 1992; 359: 195-196.

6 Rogers DF. Airway goblet cells: responsive and adaptable frontline defenders. Eur Respir J 1994; 7: 1690-1706.

7 Rose MC. Mucins: structure, function, and role in pulmonary diseases. Am J Physiol 1992; 263: L413-L429.

8 Voynow JA. What does mucin have to do with lung disease? Paediatr Respir Rev 2002; 3: 98-103.

9 Rose MC, Voynow JA. Respiratory tract mucin genes and mucin glycoproteins in health and disease. Physiol Rev 2006; 86: 245-278

10 Rowe SM, Miller S, Sorscher EJ. Cystic fibrosis. N Engl J Med 2005; 352: 1992-2001

11 Dohrman A, Miyata S, Gallup M, et al. Mucin gene (MUC 2 and MUC 5AC) upregulation by Gram-positive and Gram-negative bacteria. Biochim Biophys Acta 1998; 1406: 251-259.

12 Burgel PR, Montani D, Danel C, et al. A morphometric study of mucins and small airway plugging in cystic fibrosis. Thorax 2007; 62: $153-161$

13 Groneberg DA, Eynott PR, Oates T, et al. Expression of MUC5AC and MUC5B mucins in normal and cystic fibrosis lung. Respir Med 2002; 96: 81-86.

14 Garcia MA, Yang N, Quinton PM. Normal mouse intestinal mucus release requires cystic fibrosis transmembrane regulator-dependent bicarbonate secretion. J Clin Invest 2009; 119: 2613-2622.

15 Morcillo EJ, Cortijo J. Mucus and MUC in asthma. Curr Opin Pulm Med 2006; 12: 1-6.

16 Singer M, Lefort J, Vargaftig BB. Granulocyte depletion and dexamethasone differentially modulate airways hyperreactivity, 
inflammation, mucus accumulation, and secretion induced by rmIL-13 or antigen. Am J Respir Cell Mol Biol 2002; 26: 74-84.

17 Rogers DF. The role of airway secretions in COPD: pathophysiology, epidemiology and pharmacotherapeutic options. COPD 2005; 2: 341-353.

18 Konstan MW, Walenga RW, Hilliard KA, et al. Leukotriene B4 markedly elevated in the epithelial lining fluid of patients with cystic fibrosis. Am Rev Respir Dis 1993; 148: 896-901.

19 Kim YD, Kwon EJ, Park DW, et al. Interleukin-1beta induces MUC2 and MUC5AC synthesis through cyclooxygenase-2 in NCIH292 cells. Mol Pharmacol 2002; 62: 1112-1118.

20 Borot F, Vieu DL, Faure G, et al. Eicosanoid release is increased by membrane destabilization and CFTR inhibition in Calu-3 cells. PLOS One 2009; 4: e7116.

21 Ghosh M, Tucker DE, Burchett SA, et al. Properties of the Group IV phospholipase A2 family. Prog Lipid Res 2006; 45: 487-510.

22 Six DA, Dennis EA. The expanding superfamily of phospholipase A(2) enzymes: classification and characterization. Biochim Biophys Acta 2000; 1488: 1-19.

23 Peters-Golden M, Canetti C, Mancuso P, et al. Leukotrienes: underappreciated mediators of innate immune responses. J Immunol 2005; 174: 589-594.

24 Tilley SL, Coffman TM, Koller BH. Mixed messages: modulation of inflammation and immune responses by prostaglandins and thromboxanes. J Clin Invest 2001; 108: 15-23.

25 Bonventre JV, Huang Z, Taheri MR, et al. Reduced fertility and postischaemic brain injury in mice deficient in cytosolic phospholipase A2. Nature 1997; 390: 622-625.

26 Nagase T, Uozumi N, Ishii S, et al. A pivotal role of cytosolic phospholipase $\mathrm{A}(2)$ in bleomycin-induced pulmonary fibrosis. Nat Med 2002; 8: 480-484.

27 Uozumi N, Kume K, Nagase $\mathrm{T}$, et al. Role of cytosolic phospholipase A2 in allergic response and parturition. Nature 1997; 390: 618-622.

28 Snouwaert JN, Brigman KK, Latour AM, et al. An animal model for cystic fibrosis made by gene targeting. Science 1992; 257: 1083-1088.

29 Nagase T, Uozumi N, Aoki-Nagase T, et al. A potent inhibitor of cytosolic phospholipase A2, arachidonyl trifluoromethyl ketone, attenuates LPS-induced lung injury in mice. Am J Physiol Lung Cell Mol Physiol 2003; 284: L720-L726.

30 Chignard M, Balloy V. Neutrophil recruitment and increased permeability during acute lung injury induced by lipopolysaccharide. Am J Physiol Lung Cell Mol Physiol 2000; 279: L1083-L1090.

31 Haile S, Lefort J, Joseph D, et al. Mucous-cell metaplasia and inflammatory-cell recruitment are dissociated in allergic mice after antibody- and drug-dependent cell depletion in a murine model of asthma. Am J Respir Cell Mol Biol 1999; 20: 891-902.

32 Yanagihara K, Seki M, Cheng PW. Lipopolysaccharide induces mucus cell metaplasia in mouse lung. Am J Respir Cell Mol Biol 2001; 24: 66-73.

33 Burgel PR, Lazarus SC, Tam DC, et al. Human eosinophils induce mucin production in airway epithelial cells via epidermal growth factor receptor activation. J Immunol 2001; 167: 5948-5954.

34 Filgueiras OM, Possmayer F. Characterization of phospholipase A2 from rabbit lung microsomes. Lipids 1987; 22: 731-735.

35 Hidi R, Vargaftig BB, Touqui L. Increased synthesis and secretion of a 14-kDa phospholipase A2 by guinea pig alveolar macrophages. Dissociation from arachidonic acid liberation and modulation by dexamethasone. J Immunol 1993; 151: 5613-5623.
36 Ollero M, Laposata M, Zaman MM, et al. Evidence of increased flux to $\mathrm{n}-6$ docosapentaenoic acid in phospholipids of pancreas from Cftr-- knockout mice. Metabolism 2006; 55: 1192-1200.

37 Kohri K, Ueki IF, Nadel JA. Neutrophil elastase induces mucin production by ligand-dependent epidermal growth factor receptor activation. Am J Physiol Lung Cell Mol Physiol 2002; 283: L531-L540.

38 Burgel PR, Nadel JA. Roles of epidermal growth factor receptor activation in epithelial cell repair and mucin production in airway epithelium. Thorax 2004; 59: 992-996.

39 Perez A, Issler AC, Cotton CU, et al. CFTR inhibition mimics the cystic fibrosis inflammatory profile. Am J Physiol Lung Cell Mol Physiol 2007; 292: L383-395.

40 Okamoto K, Kim JS, Rubin BK. Secretory phospholipases A2 stimulate mucus secretion, induce airway inflammation, and produce secretory hyperresponsiveness to neutrophil elastase in ferret trachea. Am J Physiol Lung Cell Mol Physiol 2007; 292: L62-L67.

41 Davidson DJ, Dorin JR, McLachlan G, et al. Lung disease in the cystic fibrosis mouse exposed to bacterial pathogens. Nat Genet 1995; 9: 351-357.

42 Cressman VL, Hicks EM, Funkhouser WK, et al. The relationship of chronic mucin secretion to airway disease in normal and CFTRdeficient mice. Am J Respir Cell Mol Biol 1998; 19: 853-866.

43 Berguerand M, Klapisz E, Thomas G, et al. Differential stimulation of cytosolic phospholipase A2 by bradykinin in human cystic fibrosis cell lines. Am J Respir Cell Mol Biol 1997; 17: 481-490.

44 Miele L, Cordella-Miele E, Xing M, et al. Cystic fibrosis gene mutation (deltaF508) is associated with an intrinsic abnormality in $\mathrm{Ca}^{2+}$-induced arachidonic acid release by epithelial cells. DNA Cell Biol 1997; 16: 749-759.

45 Chap H. Une homologie frappante entre CFTR et les annexines [A striking homology between CFTR and annexins]. Médecine/Science 1991; 7: 8-9.

46 Flower RJ, Rothwell NJ. Lipocortin-1: cellular mechanisms and clinical relevance. Trends Pharmacol Sci 1994; 15: 71-76.

47 Kim S, Ko J, Kim JH, et al. Differential effects of annexins I, II, III, and $\mathrm{V}$ on cytosolic phospholipase A2 activity: specific interaction model. FEBS Lett 2001; 489: 243-248.

48 Engelhardt JF, Yankaskas JR, Ernst SA, et al. Submucosal glands are the predominant site of CFTR expression in the human bronchus. Nat Genet 1992; 2: 240-248.

49 Lukacs GL, Mohamed A, Kartner N, et al. Conformational maturation of CFTR but not its mutant counterpart ( $\Delta$ F508) occurs in the endoplasmic reticulum and requires ATP. Embo J 1994; 13: 6076-6086.

50 Borthwick LA, McGaw J, Conner G, et al. The formation of the cAMP/protein kinase A-dependent annexin 2-S100A10 complex with cystic fibrosis conductance regulator protein (CFTR) regulates CFTR channel function. Mol Biol Cell 2007; 18: 3388-3397.

51 Trouve P, Le Drevo MA, Kerbiriou M, et al. Annexin V is directly involved in cystic fibrosis transmembrane conductance regulator's chloride channel function. Biochim Biophys Acta 2007; 1772: 1121-1133.

52 Chung YW, Oh HY, Kim JY, et al. Allergen-induced proteolytic cleavage of annexin-1 and activation of cytosolic phospholipase A2 in the lungs of a mouse model of asthma. Proteomics 2004; 4: 3328-3334.

53 Bensalem N, Ventura AP, Vallee B, et al. Down-regulation of the anti-inflammatory protein annexin A1 in cystic fibrosis knock-out mice and patients. Mol Cell Proteomics 2005; 4: 1591-1601. 